\title{
In situ flip of a glistened upside down multipiece IOL to relieve pupillary block
}

\author{
Sudarshan Khokhar, Amber Amar Bhayana 두, Mousumi Banerjee, Anirudh Kapoor
}

Ophthalmology, Dr Rajendra Prasad Centre for Ophthalmic Sciences, All India Institute of Medical Sciences, New Delhi, Delhi, India

\section{Correspondence to}

Dr Amber Amar Bhayana; amber.amar.bhayana@gmail. com

Accepted 20 October 2020

Check for updates

(c) BMJ Publishing Group Limited 2020. No commercial re-use. See rights and permissions. Published by BMJ.

\begin{tabular}{l} 
To cite: Khokhar $\mathrm{S}_{\text {, }}$ \\
Bhayana AA, Banerjee M, \\
et al. BMJ Case Rep \\
2020;13:e239451. \\
doi:10.1136/bcr-2020- \\
239451 \\
\hline
\end{tabular}

\section{DESCRIPTION}

A 28-year-old man, left eye pseudophakic (operated for post-traumatic corneal perforation with lens rupture 4 years ago) presented with intermittent episodes of left eye redness, diminution of vision with pain in left eye and left side of head for the past 1 year; episodes lasting for $10-15 \mathrm{~min}$ and the frequency of episodes was increasing for the past 2 months. Best corrected visual acuity (BCVA) in the both eyes were 20/20. Left eye had a refractive error of $-0.5 \mathrm{DS}$ spherical equivalent. Left eye (figure 1A) showed a multipiece acrylic intraocular lens (IOL) (figure 1A,B) placed in the sulcus in the shape of ' $\mathrm{S}$ ' configuration with optic captured at pupil with posterior capsular opening (figure 1A). The upside down nature of the lens and the pupillary capture was further confirmed on anterior segment optical coherence tomography (figure 1B). Right eye was normal. Intraocular pressures (IOPs) and posterior segments bilaterally were within normal limits. Once called during the episode, left eye had vision of 20/100, with microcystic corneal oedema, congestion and an IOP of $40 \mathrm{~mm} \mathrm{Hg}$. A diagnosis of acute pupillary block leading to ocular hypertension secondary to upside down insertion of multipiece IOL was made. Patient was planned for an IOL flip.

Preoperatively specular microscopy was tried but endothelial cell count could not be captured (because of recurrent episodes of corneal oedema). During surgery (figure 2A) after the anterior segment was filled with viscoelastic, the IOL was first exteriorised into the anterior chamber by dialling out the IOL in anticlockwise direction (figure $2 \mathrm{~B}$ ). Then with the help of a sinksey hook and a viscoelastic canula, the IOL was flipped along the axis as shown in the anterior chamber (figure 2C,D), then dialled back into the sulcus in clockwise direction (figure 2E,F). Postoperatively vision was $20 / 20$ at day 1 and 3 weeks follow-up, with IOP within normal limits with no similar episodes until now (2 months). Specular microscopy after 2 months showed an endothelial cell count of $2017 / \mathrm{mm}^{2}$.

In the bag IOL implantation during cataract surgery is the most physiological place for an IOL to be. But in case of lack of anterior or posterior capsular support, ciliary sulcus is another place where lens can be implanted. Multipiece IOLs are the lenses of choice here. These foldable IOLs are available in different models, the one used here (AcrySof MA60AC) has an optic diameter of $6 \mathrm{~mm}$ and haptics of $13 \mathrm{~mm}$ (figure 1B). The optic is made of acrylic and haptics are made of polymethylmethaacrylate. Common indications
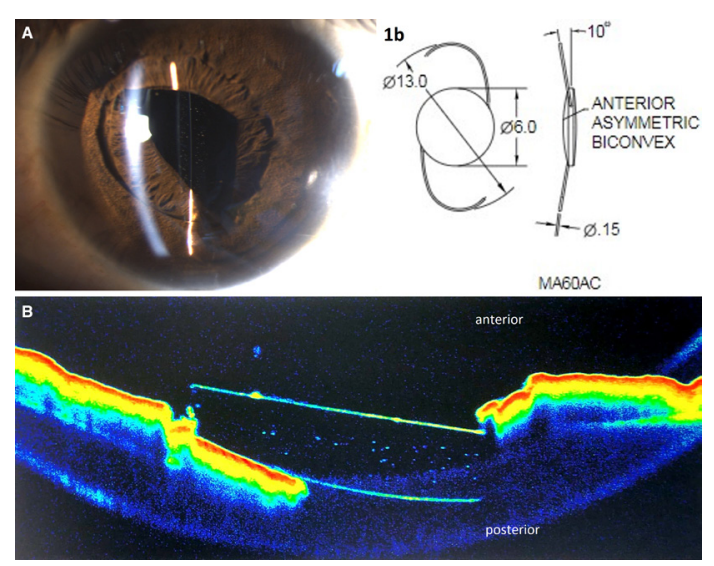

Figure 1 (A) Left eye showing multipiece IOL in sulcus with early glistening with pupillary capture. (B) Model of ACRYSOF MA60 multipiece IOL. (C) Anterior segment optical coherence tomography showing the IOL captured in pupillary plane, glistening as hyperreflective dots in the $\mathrm{IOL}$ and upside down nature of IOL as seen by anterior flat surface and posterior curved surface of IOL when compared with $\mathrm{B}$.

for implanting the lens include posterior capsular tear with intact anterior capsular rim, secondary lens implantation with atleast $270^{\circ}$ capsular rim support, in paediatric eyes after aspirations of partially absorbed cataract. The lens has a posterior angulation between the optic and the haptic of $10^{\circ}$ when implanted in the conventional ' 2 ' configuration (figure 1B). But if implanted upside down in ' $\mathrm{S}$ ' configuration the optic comes anterior and can cause pupillary block ${ }^{12}$ apart from myopic shift as in our case. Incorrect positioning of IOL in sulcus has been reported to occur in 1.3\% of cases in most experienced hands. ${ }^{3}$ We did an in vivo IOL flip ${ }^{4}$ and the patient was relieved of his symptoms. The advantage of an in vivo flip was that the need for
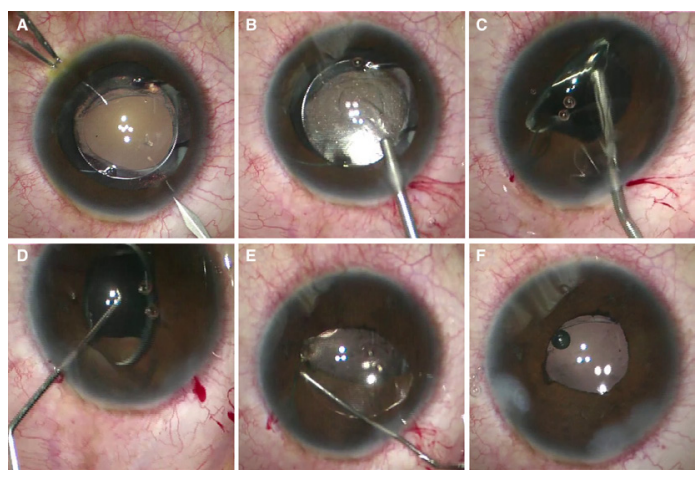

Figure 2 Steps of the IOL flip surgery. 


\section{Learning points}

Inserting a vaulted lens upside down increases chances of pupillary block and its optic being captured in the pupil.

- In vivo flipping is the procedure of choice in these cases provided anterior chamber depth allows manoeuvring without any damage to endothelium.

a large corneal wound for IOL explant was bypassed negating all its consequences like corneal sutures leading to astigmatism, vitreous loss, chances of damage to IOL while exteriorizsing.

Thus we would like to report a rare sequelae due to minor carelessness during IOL implantation which can cause significant morbidity and land the person back on operating table years later. Luckily in our case posterior capsular defect with anterior vitrectomy already done allowed sufficient space in anterior chamber after filling with viscoelastic to allow this in vivo flip to be safely performed without any collateral damage to iris, cornea or angles.
Contributors SK helped in writing the concept and manuscript editing. AAB performed the surgery and preparation of manuscript. MB helped in photographic documentation and retrieval of data. AK helped in the review of literature.

Funding The authors have not declared a specific grant for this research from any funding agency in the public, commercial or not-for-profit sectors.

Competing interests None declared.

Patient consent for publication Obtained.

Provenance and peer review Not commissioned; externally peer reviewed.

\section{ORCID iD}

Amber Amar Bhayana http://orcid.org/0000-0002-0770-601X

\section{REFERENCES}

1 Zhang $\mathrm{X}$, Soni N, Alexander J, et al. Pupillary block due to reverse implantation of a sulcus intraocular lens. JCRS Online Case Rep 2016;4:41-4.

2 Harsum S, Low S. Reversed vaulted ACRYSOF intraocular lens presenting as pupillary block. Eye 2009;23:1880-2.

3 Halpern BL, Gallagher SP. Refractive error consequences of reversed-optic AMO SI40NB intraocular lens. Ophthalmology 1999;106:901-3.

4 Khng CYW, Yeo K-T. The IOL FLIP: rescue for foldable lens implantation gone wrong. $\mathrm{Br}$ J Ophthalmol 2003;87:656-7.

Copyright 2020 BMJ Publishing Group. All rights reserved. For permission to reuse any of this content visit

https://www.bmj.com/company/products-services/rights-and-licensing/permissions/

BMJ Case Report Fellows may re-use this article for personal use and teaching without any further permission.

Become a Fellow of BMJ Case Reports today and you can:

- Submit as many cases as you like

- Enjoy fast sympathetic peer review and rapid publication of accepted articles

- Access all the published articles

Re-use any of the published material for personal use and teaching without further permission

Customer Service

If you have any further queries about your subscription, please contact our customer services team on +44 (0) 2071111105 or via email at support@bmj.com.

Visit casereports.bmj.com for more articles like this and to become a Fellow 